\title{
Evaluation of Level of Precursors of N-Nitrosamine in Vitro in Wistar Rats Fed Different Levels of Dietary Protein
}

\author{
${ }^{*}$ Akpabio, C. J. ${ }^{1}$ Efuruibe, A. A., ${ }^{2}$ Ogunsola, M. O., ${ }^{3}$ Adeleke, G. E. and \\ ${ }^{1}$ Maduagwu, E. N. \\ ${ }^{I}$ Department of Biochemistry, Faculty of Basic Medical Sciences, University of Ibadan, Ibadan, Oyo State \\ Nigeria. \\ ${ }^{2}$ Department of Biochemistry, Faculty of Science, Bowen University, Iwo, Osun State, Nigeria. \\ ${ }^{3}$ Department of Biochemistry, Faculty of Science, Ladoke Akintola University of Technology, Ogbomoso, Oyo \\ State, Nigeria.
}

\begin{abstract}
This study compares the level of Nitrite in urine, protein concentration and nitrite concentration in post mitochondrial fraction of rats fed different levels of dietary protein with concurrent administration of precursors of $\mathrm{N}$-nitrosamine; dimethylamine hydrochloride $(\mathrm{DMA}-\mathrm{HCl})$ and sodium nitrite $\left(\mathrm{NaNO}_{2}\right)$. Thirty Male Wistar rats were divided into three groups and were kept for four weeks. Group one was given high protein diet (64\%), group two was given a normal protein diet (27\%) and group three was given low protein

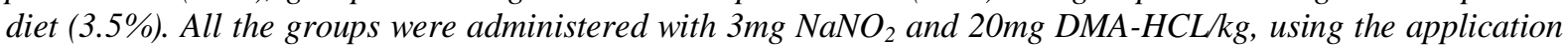
of spectrophotometric analysis, centrifugation, as well as colorimetric methods. Following administrations of the chemicals to the test animal groups, the concentration of 24 hours urinary excretion of nitrite was $7.417 \mu \mathrm{g} / \mathrm{ml}$ in high protein fed rats, $2.063 \mu \mathrm{g} / \mathrm{ml}$ in normal protein fed rats and $0.569 \mu \mathrm{g} / \mathrm{ml}$ in low protein fed rats. There was a significant difference $(p<0.05)$ in the nitrite concentration in the group fed high protein diet with concurrent administration of $\mathrm{NaNO}_{2}$ and $\mathrm{DMA}-\mathrm{HCl}$. The wistar rats fed with high protein diet, excreted 5.8 to 7 times more nitrite in urine than the severely protein deprived animals. The protein and nitrite concentration of the post mitochondrial fraction of liver was highest in rats that were fed high protein diet. This study has revealed that nutrition status affects metabolism of foreign compounds including nitrites and dimethylamine hydrochloride.
\end{abstract}

.Key words: Dietary protein, Dimethylamine hydrochloride, metabolism, Sodium Nitrite, Urine.

\section{Introduction}

Protein is an essential nutrient that is important to human health. Protein consists of chains of amino acids that are used by the body to grow muscles, hair, nails, skin and internal organs. Although protein is an essential nutrient, some researchers suggest that too much protein can increase the risk of developing heart disease, stroke, kidney stones and osteoporosis. ${ }^{1,34,35}$

Sodium nitrite $\left(\mathrm{NaNO}_{2}\right)$ is a pure white or slightly yellowish crystalline powder. It is very soluble in water and is hygroscopic. It is also slowly oxidized by oxygen in the air to sodium nitrate, $\mathrm{NaNO}_{3}$. The compound is a strong oxidizing agent. It is used as a color fixative and preservative in meats and fish, it is also used in manufacturing diazo dyes, nitroso compounds and other organic compounds; in dyeing, printing textile fabrics, bleaching fibers and in photography etc. ${ }^{2}$ Dimethylamine hydrochloride is a white to off-white crystalline free flowing powder, it has a molecular weight $81.55 \mathrm{~g}$, the melting point is $170^{\circ} \mathrm{C}$ and it decomposes at its boiling point. It is soluble in water and has a pH of $6.0-6.5$ (5.0\% sol.). Dimethylamine hydrochloride vapor causes irritation of the eyes, skin and respiratory tract in humans and animals which is manifested at lower concentrations as lacrimation and mild lesions in the nasal mucosa. At sufficiently high concentrations and/or exposure durations, animal studies reported severe nasal and lungs lesions and occasionally lesions of the liver, kidneys and testes. DMA is present in many foods including cabbage, celery, corn, fish, and coffee and is also formed endogenously by gut bacteria from DMA precursors including trimethylamine N-oxide. ${ }^{3}$

Nitrosamines are a major candidate class of carcinogens likely to be causally related to human cancer. ${ }^{4}$ Nitrosamines act systemically and produce cancer in a wide variety of organs of many species at the (parts per million) ppm dietary level, ${ }_{5}^{5}$ nitrosamines have been found in tobacco smoke, grains, and alcoholic beverages in concentrations of $<5$ ppm. ${ }^{6}$ Higher concentrations of nitrosamines, particularly dimethylnitrosamine, have been found in nitrite-preserved fish meals which were highly toxic to ruminants. Dimethylnitrosamine is formed during cooking of canned or smoked fish with nitrite. The average human daily intake of nitrite has been estimated as 22 pmoles, equivalent to $\mathrm{I} .5 \mathrm{mg}$ of $\mathrm{NaNO}_{2}$; levels in excess of this have produced acute methemoglobinemia in infants. Nitrosamines are formed chemically from the interaction of nitrites or oxides of nitrogen and secondary amines in acidic conditions. ${ }^{7,8}$ Nitrosamines can also be formed in the gastric juice of the human stomach. This is commonly referred to as endogenous nitrosation. Bacteria in the mouth chemically 
reduce nitrate, which is prevalent in many vegetables, to nitrite, which in turn can form nitrosating agents. Many foods contain amines that can react with nitrosating agents in the acidic stomach to form nitrosamines. ${ }^{9}$

Recently, on the basis of animal experiments, it was concluded that the monitoring of urinary levels of $\mathrm{N}$-nitrosoamino acids such as $\mathrm{NPRO}^{3}$ and N-nitrosohydroxyproline could be a useful procedure for the quantitative estimation of nitrosation in vivo. ${ }^{10,11}$ Thus, more than $80 \%$ of a dose of NPRO administered to rats was excreted unchanged into urine within 24 hour; in a typical experiment, the simultaneous administration of $10 \mu \mathrm{mol}$ of each proline and nitrite to rats resulted in a significant increase in urinary excretion of NPRO (24 nmol/24 hour/rat). ${ }^{12}$ Endogenous N-nitrosation was demonstrated in a male volunteer who ingested vegetable juice as a source of nitrate together with proline by quantitative monitoring of NPRO excreted into the urine. A significant increase of urinary excretion of NPRO occurred only after ingestion of nitrate and proline. The vegetable juice and proline used contained no detectable levels of preformed NPRO or nitrite. Ingestion of either of the precursors alone did not increase urinary excretion of NPRO; therefore, the NPRO excreted in the urine is most probably formed in the human body through the reaction of proline with nitrite, the latter being derived from nitrate. ${ }^{13}$

Dietary intakes of red and processed meat are of particular importance in the formation of fecal NOC. ${ }^{14}$ Higher consumption of red meat ( 600 vs. $60 \mathrm{~g} / \mathrm{day}$ ), but not white meat, resulted in a three-fold increase in fecal NOC levels. ${ }^{15}$ Studies have shown that the post mitochondrial fraction of liver tissue homogenates could decompose NDMA by oxidative dealkylation. ${ }^{16,17,18}$

The urine is one of the major routes of excretion of drugs, foreign compounds and their metabolites. The excretion of N-nitrosamines including DMA in the urine of humans and animals have been reported by researchers. ${ }^{19,20}$

This investigation has been designed to assess the effect of different levels of dietary protein intake on the excretory pattern of orally administered dimethylamine hydrochoride and sodium nitrite by comparing the urinary excretion of the unchanged nitrite (precursor of nitrosamine) in high protein, normal protein and low protein diet fed rats. Also to determine the protein and nitrite concentration in the post mitochondrial fraction in livers of rats fed different levels of dietary proteins.

\section{Experimental animal}

\section{Materials And Methods}

Thirty (30) Male experimental albino Wistar rats weighing between 70-100g were purchased from Biochemistry animal farm in the University of Ibadan, Nigeria and were kept at room temperature $\left(27^{\circ} \mathrm{C}\right)$ in standard cages at the animal house of the Biochemistry Department, University of Ibadan. They were given different levels of dietary protein which are shown in Table.1, water ad libitum and acclimatised for 4 weeks before being used for the research work.

Table 1: Composition of the Experimental Diets

\begin{tabular}{llll}
\hline & High protein $(\%)$ & Normal protein $(\%)$ & Low protein $(\%)$ \\
\hline Protein & 64 & 27 & 3.5 \\
Cornstarch & 22 & 59 & 81.5 \\
Oil & 8 & 8 & 8 \\
Vitamin & 2 & 4 & 4 \\
Mineral Salt & 4 & 2 & 3 \\
\hline
\end{tabular}

\section{Experimental group}

The rats were divided into three groups and were placed in different protein diets. Group one was given high protein diet (64\%), group two was given a normal protein diet $(27 \%)$ and group three was given low protein diet (3.5\%). Sodium Nitrite $\left(\mathrm{NaNO}_{2}\right)$ and Dimethylamine hydrochloride (DMA-HCL) were concurrently administered orally at a single dose of $3 \mathrm{mg} \mathrm{NaNO}$ and $20 \mathrm{mg}$ of DMA-HCl $/ \mathrm{kg}$ to each experimental group. All rats were starved overnight prior to administration of toxins. The weight of the rats was taken before and after oral administration.

\section{Experimental Diets}

Fish was used as a source of protein, carbohydrate was obtained from cornstarch and vegetable oil was the source of fat and oil. Emvite multivitamin tablets was the source of vitamin and different salt formulations into a salt mixture was used as source of mineral salt. In preparation of the diet, the constituents were mixed together thoroughly to achieve homogeneity. They were then made into pellets and dried in the oven for complete dryness and removal of any trace of water. The food were then stored at room temperature in large 
plastic containers and labeled according to the different groups as required. See Table 2 and 3 for vitamins and minerals mixtures used.

Table 2:Special Vitamin mixture

\begin{tabular}{lll}
\hline S/N & Vitamin & Proportion \\
\hline 1 & Vitamin A Acetate & 2500 i.u \\
2 & Vitamin B & 250 i.u \\
3 & Vitamin C & $600 \mathrm{mcg}$ \\
4 & Vitamin D & $1300 \mathrm{mcg}$ \\
\hline
\end{tabular}

Table 3: COMPOSITION OF MINERAL MIXTURE

\begin{tabular}{lll}
\hline S/N & Types of mineral & Composition \\
\hline 1 & Calcium Carbonate & $20 \mathrm{~g}$ \\
2 & Calcium Hydrogen phosphate & $10.50 \mathrm{~g}$ \\
3 & Sodium chloride & $8 \mathrm{~g}$ \\
4 & Di-potassium hydrogen phosphate & $35 \mathrm{~g}$ \\
5 & Magnesium sulphate & $8 \mathrm{~g}$ \\
6 & Manganese sulphate & $0.51 \mathrm{~g}$ \\
7 & Copper sulphate & $0.03 \mathrm{~g}$ \\
8 & Potassium iodide & $0.08 \mathrm{~g}$ \\
9 & Zinc chloride & $0.925 \mathrm{~g}$ \\
10 & Cobalt chloride & $0.005 \mathrm{~g}$ \\
11 & Ferrous sulphate & $17.85 \mathrm{~g}$ \\
\hline
\end{tabular}

Chemicals and reagents

Sodium nitrite $\left(\mathrm{NaNO}_{2}\right.$, Mol.wt 69) Dimethylamine hydrochloride $\left.\left(\mathrm{CH}_{3}\right)_{2} \mathrm{NH} . \mathrm{HCL}\right)$,

Mol.wt 81.55), were obtained from Sigma (USA).

\section{Composition of the Montgomery and Dymock Reagent for Nitrite Determination}

a. Solution A: Sulphanilic acid solution.

27.2g of Potassium hydrogen sulphate and $3.46 \mathrm{~g}$ of sulphanilic acid were dissolved in one litre doubledistilled-deionised water.

b. Solution B: Naphthylethylenediamine (NEDA) solution.

$0.4 \mathrm{~g}$ Naphthylethylenediamine dihydrohychloride was dissolve in one litre double distilled deionised water.

c. Solution C: $0.5 \%$ sodium carbonate solution.

$0.5 \mathrm{~g} \mathrm{Na}_{2} \mathrm{CO}_{3}$ was dissolved in $100 \mathrm{ml}$ double-distilled-deionised water.

Except stated, all chemicals used were of analytical grade (Analar).

\section{Collection of urine samples}

The rats were administered with $3 \mathrm{mg}$ of sodium nitrite and $20 \mathrm{mg}$ of dimethylamine hydrochloride $/ \mathrm{kg}$. Then they were placed in metabolic cages with separate facilities for collection of urine. The rats were fed with the experimental diets and drinking water was given ad libitum. Urine was collected after 24 hours. The samples were analysed daily or stored in a refrigerator at $10^{\circ} \mathrm{C}$.

\section{Determination of nitrite in urine}

The 24-hour urine was clarified by swirling with activated charcoal and filtered through Whatman No. 1 filter paper. $1 \mathrm{ml}$ of the filtrate was analyzed for nitrite using the method of Montgomery and Dymock. ${ }^{21}$

\section{Preparation of post mitochondrial fraction}

Liver were removed from the animals under urethane anaesthesia. Liver were immediately cooled with ice-cold $0.15 \mathrm{M} \mathrm{KCL}$. Gall bladder and extraneous tissue were removed and the liver weighed after rinsing and blotting. The liver tissue was homogenized with 4 volumes of $0.06 \mathrm{M}$ phosphate buffer plus $0.15 \mathrm{M} \mathrm{KCL}$ at $\mathrm{pH}$ 7.4 with a Teflon glass homogenizer. The homogenate was centrifuged at 10,000xg for 15 minutes in a high speed refrigerated centrifuge. Protein concentration was determined using the method of Gornal et $_{\text {al. }}{ }^{22}$ 


\section{Incubation Assay}

The complete incubation medium had a total of $4 \mathrm{ml}$ and combined NADP $(0.5 \mathrm{mM})$, glucose 6Phosphate $(5 \mathrm{mM}), \mathrm{MgCl}_{2}(20 \mathrm{mM}), 0.06 \mathrm{M}$ phosphate buffer, $0.15 \mathrm{M} \mathrm{KCl}$ and $2.5 \mathrm{ml}$ of post mitochondrial fraction of the liver homogenate. The concentration of sodium nitrite was 5mM and DMA-HCL was 5mM.

The incubation was carried out in a shaking water bath; temperature $37^{\circ} \mathrm{C}$ for $30 \mathrm{~min}$, the reaction was terminated by adding $2 \mathrm{ml} \mathrm{5 \%}$ TCA. Nitrite concentration was determined according to Montgomery and Dymock. $^{21}$

Statistical analysis: Data were analysed using student's T-test analysis and was expressed as mean \pm standard deviation. A level of $\mathrm{p}<0.05$ was considered statistically significant.

\section{Results}

There was a significant difference $(\mathrm{p}<0.05)$ in the nitrite level in urine in the group fed high protein diet with concurrent administration of nitrite and DMA-HCl. There was a significant difference $(\mathrm{p}<0.05)$ in the protein and nitrite concentration of post mitochondrial fraction of rats fed high protein. The nitrite concentration was highest in the rats that were fed high protein diet, followed by the rats that were fed normal proteins and the lowest concentration was seen in the rat that were fed low protein diet.

Table 4: Comparative urinary excretions of Nitrite in 24hr Urine samples of rats fed different levels of dietary protein with or without a concurrent administration Nitrite and DMA-HCl.

\begin{tabular}{llll}
\hline \multicolumn{3}{c}{ Absolute and Relative Nitrite Excretion $(\boldsymbol{\mu g} / \mathbf{m l})$} \\
\hline $\begin{array}{l}\text { Dosage of Nitrite and } \\
\text { DMA-HCL/kg }\end{array}$ & High Protein $(64 \%)$ & Normal Protein $(\mathbf{2 7 \%})$ & Low Protein (3.5\% ) \\
$3 \mathrm{mg} \mathrm{NaNO}{ }_{2}+20 \mathrm{mg}$ & $7.417 \pm 3.71$ & $2.063 \pm 0.005$ & $0.569 \pm 0.09$ \\
$\begin{array}{l}\mathrm{DMA}-\mathrm{HCl} \\
0.0 \mathrm{mg} \mathrm{NaNO}\end{array}+0.0 \mathrm{mg}$ & $2.063 \pm 0.40$ & $1.050 \pm 0.20$ & $0.230 \pm 0.19$ \\
DMA-HCl & & &
\end{tabular}

Values are mean \pm SD of 5 determinants

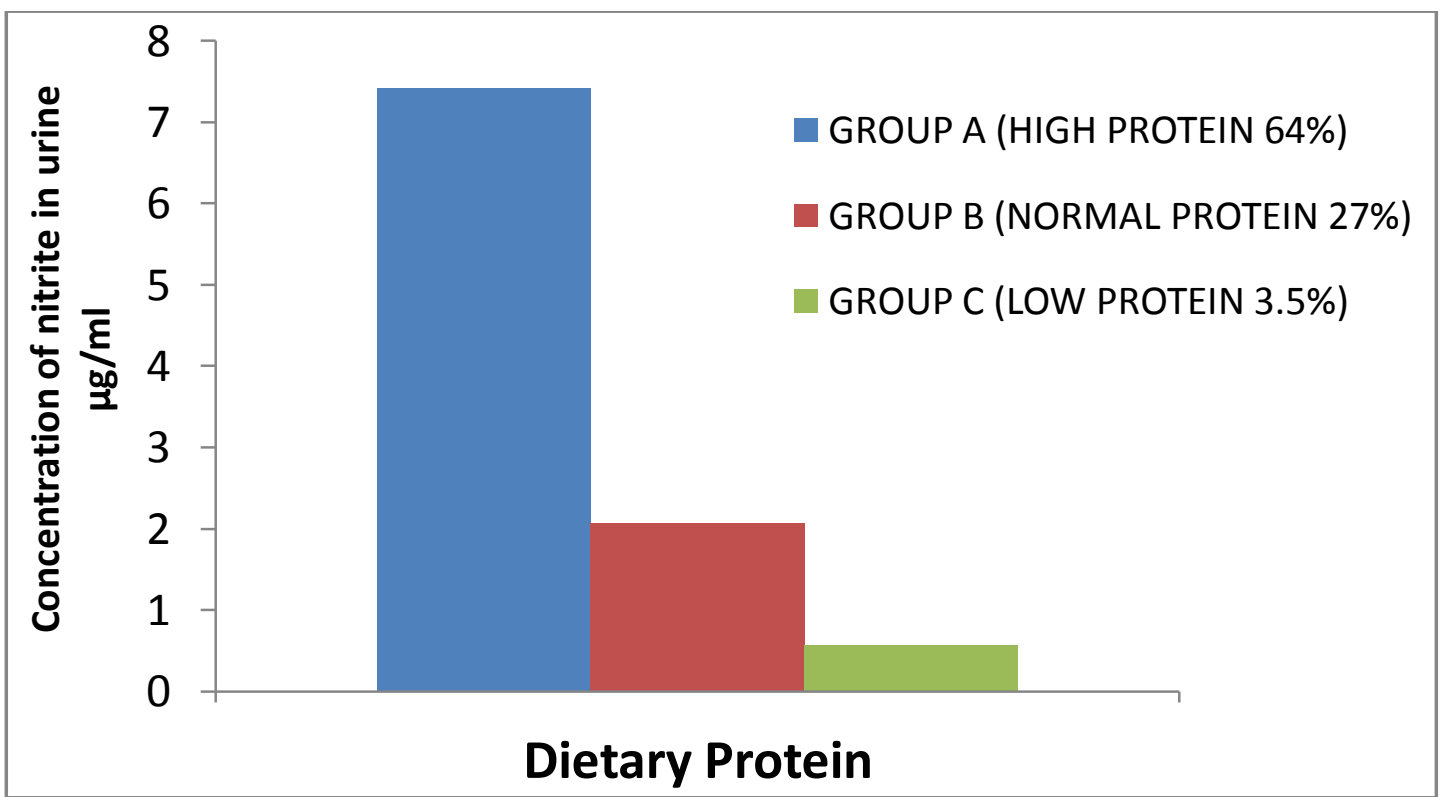

Figure 1: The level of nitrite concentration in urine of rat fed different levels of dietary protein following concurrent oral administrations of $3 \mathrm{mg} \mathrm{NaNO}$ and $20 \mathrm{mg} \mathrm{DMA}-\mathrm{HCl} / \mathrm{kg}$. 


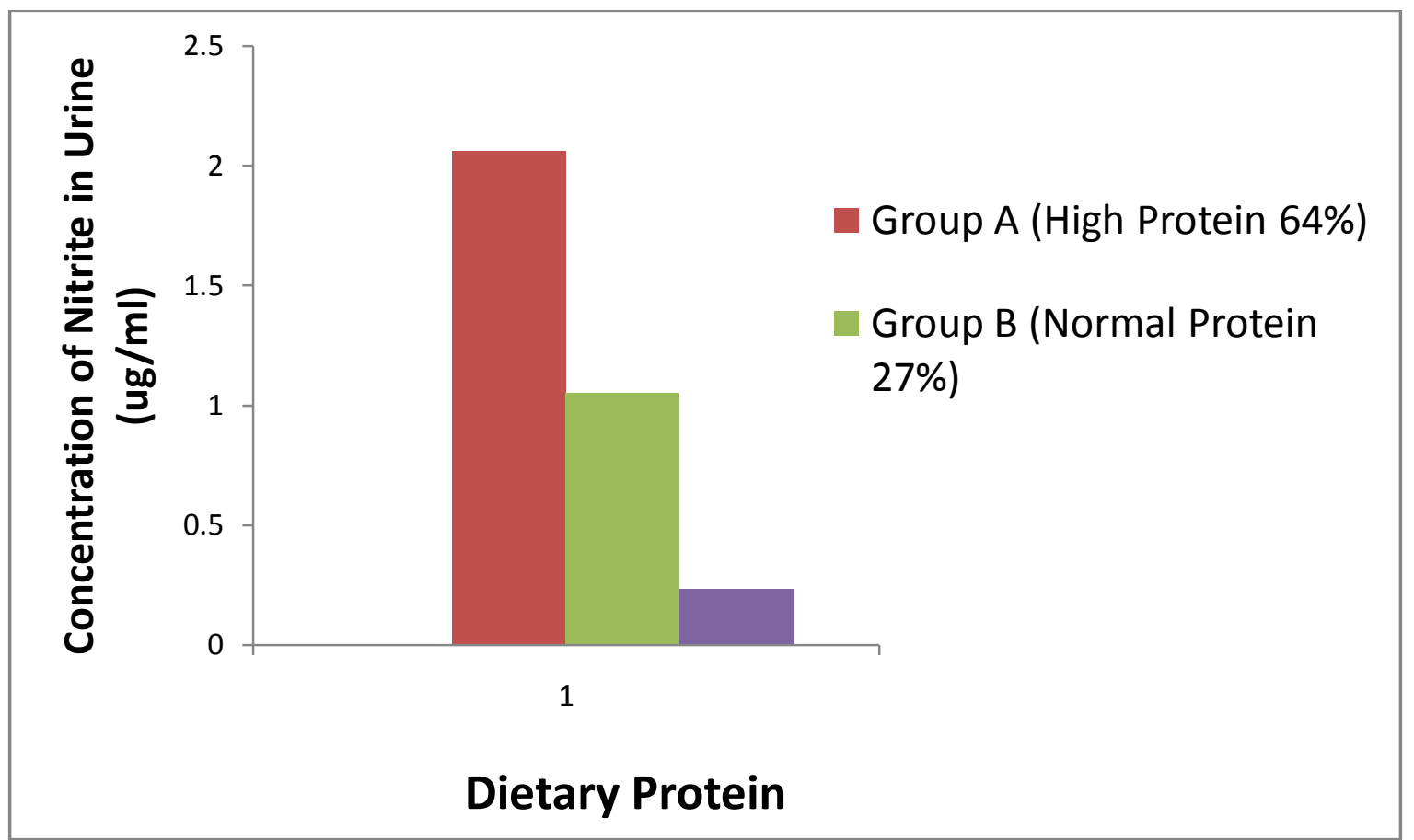

Figure 2: The level of nitrite concentration in urine of rat fed different levels of dietary protein without administration of $\mathrm{NaNO}_{2}$ and DMA-HCl.

Table 5: Protein concentration in liver microsomal plus soluble fraction of wistar albino rats fed different levels of dietary protein.

\begin{tabular}{lcc}
\hline Model Test Diet & Weight of Liver $(\mathbf{g})$ & Protein Concentration $(\boldsymbol{\mu g} / \mathbf{m l})$ \\
\hline High protein & 3.58 & $9.418 \pm 0.032$ \\
Normal protein & 3.49 & $2.139 \pm 0.822$ \\
Low protein & 2.68 & $0.432 \pm 0.046$ \\
\hline
\end{tabular}

Table 6: Nitrite concentration in liver microsomal plus soluble fraction of wistar albino rats at concentration of $5 \mathrm{mM} \mathrm{NaNO}$ and $5 \mathrm{mM}$ DMA- HCL (Combined)

\begin{tabular}{lcc}
\hline Model Test Diet & Weight of Liver $(\mathbf{g})$ & Nitrite Concentration $(\boldsymbol{\mu g} / \mathbf{m l})$ \\
\hline High protein & 3.58 & $4.033 \pm 0.52$ \\
Normal protein & 3.49 & $3.201 \pm 0.059$ \\
Low protein & 2.68 & $2.542 \pm 0.023$ \\
\hline
\end{tabular}

\section{Discussion}

Nitrosamines are present in water, soil and air. ${ }^{23}$ They can be found in contaminated food, feeding stuff (where they create the highest risk for health), drugs, cosmetics products and pesticides. ${ }^{24,25}$ Nitrosamines are absorbed by skin, airways and the alimentary tract.

Ingested nitrite is readily absorbed from the upper intestine in both rats and humans, but little absorption takes place from the stomach, distal ileum, caceum or proximal colon. ${ }^{26}$ Absorption is rapid and in humans, nitrate concentrations in body fluids (serum, saliva, urine) peaks within 1-3 hours after ingestion in food or water. ${ }^{27}$

The nutritional status in nitrite, nitrate and nitrosamine intake would play an important role in the determination of the short and long term effects arising from their ingestion in food materials. Nutrition status has been shown to affect metabolism of foreign compounds including nitrites and DMA. ${ }^{28,29,30}$

Dietary Protein altered urinary nitrite outputs in wistar rats fed with $64 \%$ protein diet; they excreted 5.8 times more than the normal protein fed rats and 7 times more nitrite in urine than the severely protein deprived animals ( as shown in Table.4 and Figure 1). This observation is consistent with reports by Montesano et al. ${ }^{31}$ The result of urinary excretion showed an excretion of nitrite in rats fed with high protein diet, normal Protein diet and low protein diet. Even though, is not a normal constituent of urine, but was obtained in urine when $\mathrm{NaNO}_{2}$ and DMA-HCL were administered to the animals. This showed that nitrite would be excretable in the urine when its concentration in circulation is sufficiently high. It also indicate that nitrite of non-bacterial origin 
can be excreted in the urine. ${ }^{30}$ Urinary excretion in response to $\mathrm{NaNO}_{2}$ load was higher for animals on high protein diet.

The results of this study showed that there was a significant difference $(\mathrm{p}<0.05)$ in the nitrite level in urine in the group fed high protein with concurrent administration of $\mathrm{NaNO}_{2}$ and DMA-HCL. The nitrite level in the high protein fed rats was the highest, followed by the rats fed with normal protein diet and the least was the rats fed with low protein diet. There was a significant difference $(\mathrm{p}<0.05)$ in the protein concentration of post mitochondrial fraction of rats fed high protein compared to the rats that fed normal protein diet and low protein diet (Table.5). In the incubation assay the result shows significant difference $(p<0.05)$ in the concentration of nitrite in the post mitochondrial fraction in the high protein fed rats compared to the normal protein fed rats and low protein diet fed rats (Table.6 ). Low-protein diets generally decrease monooxygenase activity in rat liver microsomes. The liver carcinogen dimethylnitrosamine, which must be activated metabolically, is almost without effect in protein-deficient rats. Phase II reactions may also be affected by dietary protein levels. ${ }^{32,33}$

\section{Conclusion}

This study has revealed that dietary protein alters urinary nitrite outputs in wistar rats fed with $64 \%$ protein diet; they excreted 5.8 times to 7 times more nitrite in urine respectively than the severely protein deprived animals. It also shows the significance of $\mathrm{DMA}-\mathrm{HCl}$ and $\mathrm{NaNO}_{2}$ by comparing the urinary excretion of the unchanged nitrite in high protein, normal protein and low protein diet fed rats. It also assessed the effect of different levels of dietary protein on protein concentration and nitrite concentration in post mitochondrial fraction of the liver homogenate. Hence nutrition status has been shown to affect metabolism of foreign compounds including $\mathrm{NaNO}_{2}$ and DMA-HCL.

\section{Acknowledgement}

The authors are grateful to the Biochemical Toxicology Laboratory and Central Laboratory, University of Ibadan for supplying the n-nitrosamine precursors and the equipment used for this research work and also to the Biochemistry farm for the animals supplied. They are also grateful to the entire staff of Biochemistry Department University of Ibadan.

$\begin{array}{ll}\text { Abbreviation } \\ \text { DMA-HCl } & \text { : Dimethylamine hydrochloride } \\ \text { i.u. } & : \text { International units } \\ \mathrm{KCl} & : \text { Potassium Chloride } \\ \mathrm{Kg} & : \text { Kilogram } \\ \mathrm{M} & : \text { Molar } \\ \mathrm{mcg} & \quad \text { : Microgram } \\ \mathrm{Mg} & : \text { Milligram } \\ \mathrm{MgCl}_{2} & : \text { Magnesium chloride } \\ \mathrm{mM} & : \text { Millimolar } \\ \mathrm{NADP} & : \text { Nicotineamide dinucleotide phosphate } \\ \mathrm{Na} \mathrm{CO}_{3} & : \text { Sodium Carbonate } \\ \mathrm{NaNO} & : \text { Sodium Nitrite } \\ \mathrm{NaNO} & : \text { Sodium Nitrate } \\ \mathrm{NDMA} & : \text { N-nitrosodimethylamine } \\ \mathrm{NDEA} & : \text { N-nitrosodiethylamine } \\ \mathrm{NEDA} & : \text { Naphthylenediamine } \\ \mathrm{NOC} & : \text { Nitrosocompound } \\ \mathrm{NPRO} & : \text { Nitrosoproline } \\ \mathrm{ppm} & \quad: \text { Parts per million } \\ \mathrm{RPM} & : \text { Revolution per minute } \\ \mathrm{SD} & : \text { Standard deviation } \\ \mathrm{TCA} & : \text { Trichloroacetic acid } \\ \mathrm{UV} & : \text { Ultraviolet } \\ \mu \mathrm{g} & : \text { Microgram } \\ \mu \mathrm{L} & : \text { Microlitre } \\ & \end{array}$




\section{References}

[1]. Bilsborough, S, and Neil, M. A Review of Issues of Dietary Protein Intake in Humans. International Journal of Sport Nutrition and Exercise Metabolism 2006. (16): 129-152.

[2]. Walker, C.L., Downes, L.J., Edwards, L.W., and Smith, P.L.R., Determination of a non-volatile N-nitrosamine on a food matrix, Analyst, 1993:103, 1123-1133.

[3]. Cavender, F.L., Bingham, E., Cohrssen, B. and Powell, C.H. Aliphatic and alicyclic amines in. 20 Eds., Patty's Toxicology, Volume 4, 5 th ed., Wiley, NY, 2001. pp. 686.

[4]. Franco, V.H., Hotta. J.K., Hotta, S.M., and Dos Santos JE. Plasma fatty acids in children with grade III protein-energy malnutrition in its different clinical forms: marasmus, marasmic kwashiorkor, and kwashiorkor. J. Trop. Pediatr. April 1999: 45 (2): $71-75$.

[5]. Badawi, A.F., Hosny, G., El-Hadary, M. and Mustapha, M.H. Salivary nitrate, nitrite and nitrate reductase activity in relation to risk oral cancer in Egypt DisMarkers.1998:14:91-97.

[6]. Magee, P.N. and Faber, F. Toxin liver injury and carcinogenesis, methylation of rat liver nucleic acids by dimethylnitrosamine in vivo. Biochem. J. 1962. 83:114-124.

[7]. Sen, N.P., Smith, D.C. and Schwinghamer, L. Formation of N-Nitrosamines from Secondary Amines and Nitrite in Human and Animal Gastric Juice. Food Cosmet. Toxicol., 1969 7: 301-307.

[8]. Khodaday, M., Shahryari, T., Dorri Sharifzadah, H. and Ziyazade, G.R. Evaluation of nitrite in meat products (sausages and salami) are distributed in Birjand in 2012 A, Euro. Journ. of Exp. Bio., 2012, 2 (6):2120-2124.

[9]. Mirvish, S.S., Bulay, O., Runge, R.G. and Patii, K. Study of the carcinogenicity of large doses of dimethylnitramine, W-nitroso-Lproline, and sodium nitrite administered in drinking water to rats. J. Nati. Cancer Inst..1980 64:1435-1442.

[10]. Kamiyama, S., Ohshima, H., Shimada, A., Saito, N., Bourgade, M.C., Ziegler, P., and Bartsch, H. Urinary excretion of Nnitrosoamino acids and nitrate by inhabitants of high- and low-risk areas for stomach cancer in northern Japan. IARC Sci. Publ. 1987 84:479-502.

[11]. Lu, S.H., Ohshima, H., and Fu, H.M. Urinary excretion of N-nitrosamino acids and nitrate by inhabitants of high- and low-risk areas for esophageal cancer in Northern China: endogenousformation of nitrosoproline and its inhibition by vitamin C. Cancer Res, 1986 46:1485-1491.

[12]. Ohshima, H. and Bartsch, H. Formation of N-nitroso compounds in vivo and the inhibitory effect of vitamin C. Appi. Sci., 1981 .

[13]. Ishiwata, H., Boriboon, P., Nakamura, Y., Harada, M., Tanimura, A. and Ishidate, M. Studies on in vivo formation of nitroso compounds (II) Changes of nitrite and nitrate concentrations in human saliva after ingestion of vegetables or sodium nitrate. J. Food Hyg. Soc. Japan, 1975. 16: 19-24.

[14]. Bingham, S.A, Pignatelli, B., Pollock, J.R., Ellul, A., Malaveille, C. and Gross, G., Does increased endogenous formation of $N$ nitroso compounds in the human colon explain the association between red meat and colon cancer? Carcinogenesis. 1996;17:515523 .

[15]. Bingham, S.A., Hughes, R. and Cross, A.J. Effect of white versus red meat on endogenous $N$-nitrosation in the human colon and further evidence of a dose response. J Nutr. 2002; 132:3522S-3525S.

[16]. Souliotis, V.L., Henneman, J.R., Reed, C.D., Chhabra, S.K., Diwan, B.A. and Anderson, L.M. DNA adducts and liver DNA replication in rats during chronic exposure to N-nitrosodimethylamine (NDMA) and their relationships to the dose-dependence of NDMA hepatocarcinogenesis. Mutat Res 2002. 500(1-2):75-87.

[17]. Magee, P.N. Toxin liver injury. The metabolism of dimethylnitrosamine. Biochem. J. 1956 64: 676-682.

[18]. Magee, P.N. and Vandekar, M. Toxic liver injury; the metabolism of dimethylnitrosamine in vitro. Biochem J. 1958 Dec; 70(4):600-605.

[19]. Alam, B.S., Saporoschetz, I.B. and Epstein, S.S. Formation of N-Nitrosopiperidine from Piperidine and Sodium Nitrite in the Stomach and the Isolated Intestinal Loop of the Rat. London, Nature archives, 1987. ISSN: 1476-4687.

[20]. Magee, P.N. and Barnes, J.M. The production of malignant primary hepatic tumors in rats feeding dimethylnitrosamine $B r$. $L$. Cancer, 1967. 10:114-122.

[21]. Montgomery, H.A.C. and Dymock, J.F. The determination of nitrite in water. Analyst, 1961, 86: 414-416.

[22]. Gornal, A.G., Bardawill, C.J. and David, M.M. Determination of serum protein by means of Biuret reaction. J. Biol. Chem. 1949. 177: 571-576.

[23]. Pan, X., Zhang, B., Cox, S.B., Anderson, T.A. and Cobb, G.P. Determination of N-nitroso derivatives of hexahydro-1,3,5-trinitro1,3,5-triazine (RDX) in soils by pressurized liquid. J. Chromatogr. A, 2006, 1107(1-2): 28.

[24]. Schothorst, R.C. and Somers, H.H.J. Determination of N-nitrododie-thanolamine incosmetic products by LC-MS-MS [J]. Anal. Bioannal. Chem., 2005, 381: 681-685.

[25]. Flower, C.S., Carter, A., Earls, R., Fowler, S., Hewlins, S., Lalljie, M., Lefebvre, J., Mavro, D.S. and Volpe, N. A method for the determination of N-nitrosodiethanolamine in personal care products - collaboratively evaluated by the CTPA Nitrosamines Working Group. Int. J. Cosmet. Sci.2006, 28: 21-33.

[26]. Bartholomew, B. and Hill, M.J. The pharmacology of dietary nitrate and the origin of urinary nitrate. Food Chem. Toxicol. 1984. 22 (10): 789-795.

[27]. Alam, B.S., Saporoschetz, I.B. and Epstein, S.S. The Synthesis of Nitrosopiperidine from Nitrate and Piperidine in the Stomach and Small Intestine and in Isolated Gastric Contents of Rats. London, Nature archives, 1989 ISSN: 1476-4687.

[28]. Swann, N.P., Smith, D.C. and Schwinghamer, L. Formation of N-Nitrosamines from Secondary Amines and Nitrite in Human and Animal Gastric Juice. Food Cosmet. Toxicol., 1971.7: 301-307.

[29]. Maduagwu, E.N., Spiegehalder, B. and Preussmann, R. Nitrosamine metabolism in Kwashiokor rats. J. Bio. Pharm. 1983 32: (23): 3577-3581.

[30]. Maduagwu, E.N. Nitrosamine metabolism in protein deficient weanling rats during the process of repletion. Ann. Nutri. Metab. 1989 33: 49-56.

[31]. Montesano, R. and Bartsch, H. Mutagenic and carcinogenic N-nitroso compounds: possible environmental hazards, Mutat. Res., 1976. 32, 179-228.

[32]. Spiegelhalter, B., Elsenbrand, G. and Preussman, R. Influence of dietary nitrate on nitrite content of human saliva: possible relevance to in vivo formation of N- nitroso compounds. Food Cosmet Toxicol. 1976; 14:545-548.

[33]. Hodgson, E. and Goldstein, J.A. Metabolism of toxicants: Phase I reactions and pharmacogenetics. In Introduction to Biochemical Toxicology, 3rd ed., New York: Wiley, 2001.

[34]. Nelson, M. Find out how consuming too much protein can harm your body. www.medicinenet.com 2002. Visited March 2013.

[35]. Leong, K. Can you eat too much protein? The health consequences of a high protein diet. .http://m.voices.yahoo/can-you-eat-toomuch-protein-health-consequences-1523119.html. 2008. Visited March 2013. 